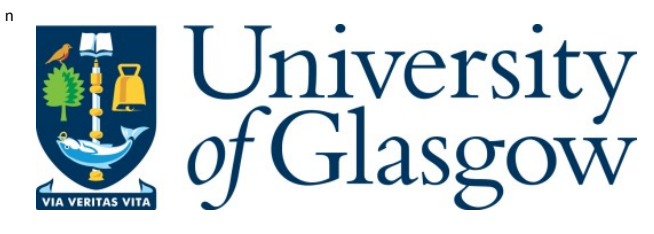

Henderson, L. (2013) Folk belief and Scottish traditional

literatures. In: Dunnigan, S. and Gilbert, S. (eds.) The Edinburgh

Companion to Scottish Traditional Literatures. Series: Edinburgh

companions to Scottish literature . Edinburgh U niversity Press, Edinburgh, pp. 26-34. ISB N 9780748645404.

Copyright (c) 2013 Edinburgh University Press

A copy can be downloaded for personal non-commercial research or study, without prior permission or charge

Content must not be changed in any way or reproduced in any format or medium without the formal permission of the copyright holder(s)

http://eprints.gla.ac.uk/100976/

Deposited on: 19 J anuary 2015

Enlighten - Research publications by members of the U niversity of Glasgow http://eprints.gla.ac.uk 


\section{Folk Belief and Scottish Traditional Literatures}

Lizanne Henderson

This chapter is concerned with supernatural belief systems and traditions, such as witches, fairies, brownies, and second sight, and the ways in which they have manifested in various forms of Scottish traditional literature. This chapter will be concerned primarily with folk narrative, which can be split into two main genres of folktale and legend, and further divided into various sub-genres. Folktale, for instance, includes the märchen or wonder tale, animal tale, novella, jocular tale (numbskull or noodle tale), schwänke, or merry tale, and the tall tale. Legend can incorporate aetiological, religious, supernatural, historical, personal (anecdote and memorate), and place. Within these broad categorisations there is much overlap and inter-relatedness.

Like folk literature, folk belief has also undergone several scholarly attempts towards a definition. In the sixteenth and seventeenth centuries, when arguably folk belief was under attack as never before, the agenda was primarily concerned with separating 'supernatural or magical beliefs, as held by the folk, from supernatural or magical beliefs, as expressed in religion'. ${ }^{1}$ By the eighteenth and nineteenth centuries, the focus was redirected predominantly towards debasing folk beliefs as relics of superstition and signs of backwardness, no longer befitting of the enlightened and civilised world. Somewhat contradictory to this view was the concomitant rise in folklore collecting that was well underway by the mid-nineteenth century. The term 'folklore' was itself invented by W illiam Thoms in 1846, in part a response to the fear that folkloric customs and traditions were fast dying out and had to be saved for posterity. Regrettably, in B ritain at least, 'folklore' often carried a pejorative sense, a problem that has far from vanished from its current usage.

Folk literature's multiformity is one of the characteristics that mark it out from high literature. While the latter exists as a set version of a specific text, written by an acknowledged author, the former can exist in multiple variations and is multi-authored. Indeed the 'author', as such, is generally unknown and it can be a fruitless task trying to establish the date of original composition or geographical provenance. In the early days of folk literature collecting, which picked up pace in the nineteenth century, the historicgeographic method was favoured. This was basically an attempt to recover all known versions of a story in pursuit of the archetype, or Ur-text, of the tale. It was a highly comparative approach, attempting to trace the international path of the story back to its original source. By the mid-twentieth century the pursuit for origins was mostly abandoned in favour of a contextualist approach, which emphasised instead the social context and performative aspects of the tale. There are also certain structural characteristics that have 
been detected in folk literature, by such pioneering folk narrative scholars as A xel Olrik who noted the tendency of folktale to concentrate on a single plot strand, patterning and repetition, and the 'law of three' - and V ladimir Propp, who discerned twenty-one character functions in folktale. ${ }^{2}$ Reidar Christiansen's list of migratory legend, as well as Stith Thompson's motif-index, and his work with Antti Aarne on the categorisation of folktale into basic types, have also been hugely influential in how we understand and interpret folk narrative. $^{3}$

A ntiquarians and folklore collectors of the eighteenth to the early twentieth centuries often lamented what they perceived to be the death of folk beliefs, customs, traditionary tales and legends, in the wake of rising literacy rates and educational advancements, as if folklore was an innocent victim of progress and the civilising process. William M otherwell harkened back to past days when 'it was a common country pastime of a winter's night to while time away by repeating proverbs, telling tales, and reciting songs and ballads; but these old fashions are fast disappearing since the schoolmaster and politics were let loose upon the country'. ${ }^{4}$ R obert Chambers (1802-1871), from Peebles, described the folktales he collected 'of a simple kind, befitting the minds which they were to regale [... ] they breathed of a time when society was in its simplest elements, and the most familiar natural things were as yet unascertained from the supernatural'. The material he collected was, he said, 'the production of rustic wits' or 'the whimsies of mere children, and were originally designed for no higher purpose than to convey the wisdom or the humours of the cottage, to soothe the murmurs of the cradle, or enliven the sports of the village green'. He cautions his reader 'not to expect here anything profound, or sublime, or elegant, or affecting [... ] the absence of high-wrought literary grace is compensated by a simplicity coming direct from nature'. ${ }^{5}$

David Buchan thought that in comparison with other European nations, Scotland had been neglectful of studying its traditional literature, though he admitted the 'vineyard has not been empty', reserving particular praise for Chambers's work; his Popular Rhymes of Scotland (1826; revd ed. 1870) was considered an early attempt to present a 'multigeneric view of Scottish folk literature'. ${ }^{6}$ The ballad collections of men such as William Motherwell (1797-1835) and the American scholar Francis J. Child (1825-1896) are relatively well-known, as are the legends and tales assembled by Sir Walter Scott (17711832) and J. F. Campbell (1821-1885). Other names, however, are less familiar, such as James Napier (1810-1884) on the west of Scotland, Walter Gregor (1825-97) on the Northeast and Galloway, Allan Cunningham (1784-1842) on Dumfries and Galloway, and Hugh M iller (1802-1856) on Cromarty. 
The earliest Scottish publications to enquire into the supernatural and folk belief concerning witches and fairies include Robert Kirk's The Secret Common-Wealth (1691), George Sinclair's Satan's Invisible World Discovered (1685) and Martin Martin's Description of the Western Islands of Scotland (1703; 1716). A remarkable forerunner of such literature, by about a century, was J ames VI's D aemonologie (1597) in which the king warned that accused witches would try to pass off their diabolical experiences as encounters with fairies, in the hope of avoiding the ultimate penalty. In fact the testimony that emerged from the witch trials often had the appearance of folk narratives, as I have suggested elsewhere. ${ }^{7}$ Ayrshire witch, Bessie Dunlop, found guilty of witchcraft, consorting with fairies and a ghost, was executed in 1576. Her testimony al most certainly contains evidence of folk narrative plots and motifs now recognised as folktale and local legend, reported by Dunlop as a personal experience narrative, especially under the pressures of actual or threatened interrogation. Such evidence might also be detected in other witch trial confessions, such as that by Jonet Boyman (1572) who conjured forth a fairy man near Arthur's Seat in Edinburgh in order to procure medicinal cures from him. Alison Peirson (1588) acquired her healing skills from her uncle, who visited her from Fairyland. A mong her clients was bishop Patrick A damson of St Andrews, a controversial figure in his own right, and a detail that did not escape the attention of his most fervent critic, the poet R obert Sempill, who mercilessly satirised them both:

sorcerie and incantationes,

Reasing [raising] the devill with invocationes,

With herbis, stanes, buikis and bellis, $M$ enis members, and south rinning wellis;

Palm croces, and knottis of strease [straws],

The paring of a preistis auld tees. ${ }^{8}$

There is good internal evidence that writers such as Robert Kirk and M artin M artin relied to a considerable extent upon oral informants and tradition-bearers. Kirk, the Episcopalian minister of A berfoyle, composed his treatise, The Secret Common-Wealth, 'to suppress the impudent and growing A theisme of this age' for, as his argument goes, if the existence of such phenomena as fairies is put into question then so too is the existence of angels and, ultimately, God. In the process, he preserved invaluable evidence of local, mainly Gaelic, folk beliefs and narratives, mainly about fairies, but also second sight, brownies, ghosts, and witchcraft. ${ }^{9}$

The dangers that fairies posed to humans was well understood in Kirk's lifetime. 'Women are yet alive who tell they were taken away when in Child-bed to nurse ffayrie Children', while others reported attacks upon their livestock, 'usually said to be Elf-shot'. He reports having met a woman who had been repeatedly abducted and abused by the 
fairies. She was 'melanchollious and silent, hardly ever seen to laugh' and 'she took verie litle, or no food for several years past, she tarry'd in the fields over night, saw, and convers'd with a people she knew not'. The onset of the attacks could be traced to an occasion when the woman had wandered off in search of her sheep, became tired and fell asleep on a small hill. She was then 'transported to another place befor day'. The assumption here was that the woman had inadvertently put herself in danger by falling asleep atop a fairy residence; 'there be manie places called fayrie hills, which the mountainpeople think impious and dangerous to peel [interfere with] or discover'. It is of note that $K$ irk is the first writer known to have used the term 'fairy tale'. ${ }^{10}$

$M$ artin Martin, a physician from Skye, wrote eloquently about the 'lusbartan', or 'little people' but he was more interested in the second sight, a subject on which he was a peerless authority, and the reality of which he did not doubt. He had himself been the object of visions and he strenuously defended the integrity of seers. Like Kirk, M artin, a Gaelic speaker, drew upon his deep knowledge of the oral culture. Indeed he was, for long, one of the few $\mathrm{G}$ aels to write in English about $\mathrm{G}$ aeldom; most commentators were outsiders.

A part from the testimony of witch trials, M artin and Kirk come closest to preserving supernatural folk narratives from the earlier period. ${ }^{11}$ Folk belief is often apparent in the destructive legislation of the church or the censorious records of kirk sessions. Despite the best efforts of the godly, as well as the rise of reason during the Enlightenment, much popular 'superstition' survived into the eighteenth and nineteenth centuries when collectors began to harvest the beliefs of the folk at large, convinced as they were that such beliefs were on the point of extinction. However, although more folk narratives were being recovered there were additional concerns about authenticity.

Allan Cunningham produced a prodigious number of publications, including an edition of Robert Burns's Works and The Songs of Scotland, Ancient and Modern (1825). He also wrote several short stories involving tales of fairy abduction, 'The Haunted Ships' and 'Elphin Irving: The Fairies' Cupbearers' for his book, Traditional Tales of the English and Scottish Peasantry (1822). Notoriously, when Robert Hartley Cromek produced his Remains of Nithsdale and Galloway Song (1810) it contained many of Cunningham's own compositions fraudulently passed off to both Cromek and the book-buying public as ancient ballads and traditional songs. It should be noted that Cromek's work is still frequently plundered by folklorists unaware of the possible dubious origin of the content. Cromek thanked Cunningham for having 'beguiled the tediousness of his toil' and for drawing 'from obscurity many pieces which adorn this collection, and which, without his aid, would have eluded my research'. ${ }^{12}$ If Cunningham was an enthusiastic fraudster, Cromek was a gullible dupe. It was not unknown for writers, antiquarians and folklorists of the eighteenth and 
nineteenth centuries to present their own compositions as authentic folklore - James $M$ acpherson's 0 ssian and Thomas Percy's Reliques, after all, had shown them the way.

The appendix, supplied by Cunningham, in the Remains of Nithsdale and Galloway Song, devotes quite a large section to the history of witchcraft sketched, as he claims, from 'the popular tales of the peasantry of Nithsdale and Galloway'. Cunningham returned to the subject in 1822, in Traditional Tales of the English and Scottish P easantry, but once again, caution must be exercised for there was probably very little that was truly 'traditional' in this two-volume compendium, having apparently been largely derived from his own creative imagination. There is a lively account of a witch who specialized in cursing ships which, by its very verbosity, has more of a literary flavour than of an orally communicated story. ${ }^{13}$

Cunningham collected a story about 'The Witches Tryst' - a meeting better known el sewhere as a sabbat or coven - where 'witches and warlocks of a county were assembled' and 'are yet remembered among the peasantry with terror'. He suggests that, even in the early nineteenth century, witch belief was not yet dead among the folk of this region. 'The noted tryste of the Nithsdale and Galloway warlocks and witches was held on a rising knowe, four miles distant from Dumfries, called 'Locher-brigg Hill'. There are yet some fragments of the witches' Gathering Hymn, too characteristically curious to be omitted'.

When the grey howlet has three times hoo'd, When the grimy cat has three times mewed, When the tod has yowled three times i' the wode, At the red moon cowering ahin the cl'ud; When the stars ha'e cruppen' deep i' the drift, Lest cantrips had pyked them out o' the lift, Up horsies a' but mair adowe, Ryde, ryde for Locher-briggs-know e! ${ }^{14}$

A ccording to him witches liked to travel to these frightful gatherings on broomsticks fashioned from murdered men's bones, while others preferred to change humans into animals - specifically, in this region at least, into horses. This they did by using a magic bridle made from the shredded skin of unbaptized infants 'with bits forged in Satan's armoury'. The bridle worked by shaking it above the head of the intended victim. Two young lads of Nithsdale, Cunningham tells us, once served a widow woman who was in possession of such a magic bridle. One of the lads was plump and merry but he suddenly became very skinny and sad. The other lad asked what ailed him, to be instructed, 'lie at the bed stock an' ye'll be as lean as me'. When Halloween came, the second lad decided to try this out to find out what would happen. He struggled to stay awake, but when the midnight hour arrived his mistress approached the bedside and proceeded to shake the charmed bridle 
over his face while speaking the words 'Up horsie'. To his complete surprise he was transformed into the shape of a grey horse. The bridle was put over his head and the bit was put in his teeth while the old widow mounted his back and dug in her spurs. They took off like the wind and arrived, within minutes, at Locherbrigg Knowe. The lad was fastened tightly with the bridle to a tree and there he recognised others similarly transformed into horses. What ensued was a sight that terrified him; a hellish party of witches, engaged in lewd dancing and unspeakable obscenity. The lad prayed to Heaven to help him escape his bondage and his prayers were answered. He shook off the bridle and resumed his human shape. When the sun began to rise, the witches returned to their transport after a night of debauchery. The young lad's mistress approached him and he quickly grabbed the bridle and shook it over her head this time. She was instantly transformed into a gray mare. He got on her back and rode her back with great speed, digging the spurs into her sides until they bled. When they returned to the stable, he removed the bridle and his mistress was returned to her own shape, her feet and hands now lacerated. He swore never to tell of his night's adventure, and her part in the witches gathering; in return he was allowed to keep the bridle. $^{15}$

Cunningham relates this tale as a local legend, though stories of the magic bridle are actually fairly widespread and by no means specific to Nithsdale, or indeed Scotland. There is a M oray version and another from the Borders, 'The Blacksmith's W ife of $Y$ arrowfoot'. ${ }^{16}$ Elements of the story also appear in folktale, such as the tale-type of 'the youth transformed into a horse', and 'the magic bridle' which gives the owner power over horses. ${ }^{17}$ However, al though the sources attest that witches frequently rode on stalks, bundles of straw or on the backs of animals, they do not mention, so far as I am aware, broomsticks made from the bones of murder victims.

Elsewhere Cunningham refers to the 'insensible marks, which the second sighted searchers of witchcraft called "little uncommon figures of strawberry leaves" found on the human frame'. This is a reference to the Devil's $M$ ark, received after the witch entered into a Demonic Pact. This signature of a diabolical contract occurs in several witch accusations. $\mathrm{He}$ is also on much better attested and verifiable ground in his story of 'The Pawkie Auld Kimmer':

Kimmer can milk a hale loan o' kye,

$Y$ et sit at the ingle fu' snug an' fu' dry. ${ }^{18}$

The idea here is that the kimmer, meaning witch, possessed a magical milking peg which could extract milk from any cow in the parish. This is an example of where folk narrative merges with documentation, for one of the crimes with which Elspeth McEwen 
(1698), a convicted witch from B almaclellan, Galloway, was charged, was using a wooden pin to steal milk from her neighbours' cows by placing the pin on their udders. ${ }^{19}$

Cunningham also discusses fairies and brownies. Unlike the fairies who were notably gregarious, the brownie was a solitary creature, usually male, 'living in the hollows of trees, and recesses of old ruinous castles'. ${ }^{20}$ In appearance, brownies were variously described, as squat, shaggy, naked creatures at one extreme, but tall, handsome and well proportioned, at the other. They had a dislike of clothing or excessive gifts and, for all their hard work, only wanted a bowl of cream. Some traditions state that brownies were ordained by God to be helpers of humankind in the drudgery of their toil and labour brought on by sin; thus, they must not receive any form of payment for their assistance. ${ }^{21}$ There was also a notion that brownies were particularly helpful to women, assisting them with everything from household chores to childbirth, and that they attached themselves to particular households or families. A mong Cunningham's tales is one suggesting that family prosperity was brownie-dependent. At 'Liethin Hall', in Dumfriesshire, a brownie confided to an old woman that he had lived there for some three hundred years, when the new heir arrived he made the fatal mistake of giving the brownie meat, drink and a new outfit to wear. In great lamentation, the brownie was forced to remove himself, and with him the family's good fortune:

Ca', cuttie, ca!

$\mathrm{A}^{\prime}$ the luck o' Liethin $\mathrm{Ha}$

Gangs wi' me to Bodsbeck $\mathrm{Ha}^{\prime} .{ }^{22}$

B rownies were popularised in the early nineteenth century by such publications as the story by James Hogg (1770-1835) The Brownie of Bodsbeck (1818), in which the 'brownie' is a persecuted covenanter, and the poem by William Nicholson (1782-1849) 'The Brownie of Blednoch' (1825). Nicholson's brownie, Aiken Drum, was so admired that he entered, in tale form, the oral tradition of Galloway. He 'lived in a lan where we saw nae sky (and) dwalt in a spot where a burn rins na by' and was, like most of his species, hardworking and helpful around the household, asking for no more than a dish of brose in return for his labours. However, in the poem, this did not prevent a modest wife, offended by his nakedness, to leave out an old pair of her husband's trousers for him, forcing A iken Drum to depart.

Let the learned decide, when they convene, What spell was him and the breeks between;

For frae that day forth he was nae mair seen. ${ }^{23}$

The polymath Hugh M iller, better known for his geological discoveries, was the first person to systematically record the folklore of the north east of Scotland, notably in Scenes 
and Legends of the North of Scotland (1835). He was, like so many collectors of his generation, concerned that the stories and traditions that he learned as a child were fast dying out and it was his duty to preserve them for posterity. Growing up on the Black Isle, he had direct experience of the oral tradition and was exposed to storytelling, thus he acquired his knowledge by the fireside rather than in libraries, placing him alongside people like J ames Hogg rather than Charles K irkpatrick Sharpe or J ohn Graham Dalyell. ${ }^{24}$

Unlike modern folklorists, he was not interested in versions, motifs or performance contexts, but simply wished to share his stories with the wider world so ensuring their survival for future generations. In this endeavour he collected literally hundreds of legends, folktales, personal narratives, and local history. Miller did not go in much for formal fairy tales or märchen; most of his narrations fall under the umbrella of local legend. At the time when Miller was writing, when folklore, as a discipline, was in its infancy, there were few models to follow save for W alter Scott and Alan Cunningham both of whom, to varying degrees, were known to 'improve' or modify the stories and songs they collected. It is difficult to ascertain to what extent M iller did the same, in hopes of making the stories more cohesive or interesting, or simply to make them suitable for wider audiences. ${ }^{25}$

There are many examples where Miller presents a story as local legend, as a memory of some past event or personage. Take, for instance, his account of the witch Stine Bheag o' Tarbat (pronounced 'Shteena V aig'); ' her history, as related by her neighbours, formed, like the histories of all the other witches of Scotland, a strange medley of the very terrible and the very ludicrous'. M iller reports that she was blamed for raising a storm at sea that killed her husband and son, allegedly to prevent them from reporting her engagement in 'orgies', presumably a reference to the Witches Sabbat, to the authorities. As might be expected, living in a coastal area, she was believed to be behind other problems at sea, wrecking ships and creating storms. She was also credited with annoying a farmer by assuming the shape of a black beetle, though despite her great powers, the farmer succeeded in capturing her while in beetle form, keeping her imprisoned in his snuff-box for four days. Miller cites another incident that he dated to 1738, when a crew of fishermen, unable to return to Cromarty due to bad weather, consulted Stine Bheag for she was 'famous at this time as one in league with Satan, and much consulted by seafaring men when windbound in any of the neighbouring ports'. When the fishermen entered her cottage they allegedly saw Stine sitting on a stool in front of the fire performing a spell and muttering a 'Gaelic rhyme'. The description of her 'ruinous and weather-beaten' cottage, atop which croaked a raven, is vivid and full of detail. The flames 'glanced on the naked walls of turf and stone, and on a few implements of housewifery which were ranged along the sides, together with other utensils of a more questionable form and appearance'. In the corner stood 'a huge 
wooden trough, filled with water, from whence there proceeded a splashing bubbling no, as if it were filled with live fish [... ] sentinelled by a black cat, that sat purring on a stool beside it'. Other objects in the room included a bundle of dried herbs, the skeleton of some animal partially moulded with red clay, and a staff 'with the tail of a fish fastened to one end, and the wings of a raven to the other'. She obligingly performed a spell on the ship. The next day the men set sail for home. ${ }^{26} \mathrm{M}$ iller claimed that this last encounter was related by one of the fishermen involved, though given the date of the events (1738) he would not have heard it first-hand. It cannot be known definitively if M iller embellished these local stories in any way, though given the level of detail he imparts, and the style in which it is retold, perhaps his own storytelling techniques can be observed. Strangely, he does not seem to question parts of the accumulated legends surrounding Stine B heag, which venture into rumour and gossip. How could it have been known, for instance, that her son and husband had intended to report her for witchcraft and attendance at a witches sabbat if she murdered them before they could do so? In these legends, however, there is much that is verifiable from witchcraft lore. Witches attended sabbats just as they were known to control the wind, and were consulted about such matters long after 1738. The witch's ability to shape-shift into animal form was relatively prevalent, while the cat made a suitable pet. In normal circumstances the cottage's furnishings and fish-tank could be seen as innocuous but perhaps not in the case of a suspected witch. Herbs, skeletons, and even the staff could be seen as traditional witch equipment. Stine was, in many ways, the recognisable witch of legend.

There have been many assumptions made over the years about what constitutes 'folklore' which has in turn, to some extent, predetermined what is understood as 'folk literature', namely that it shares a close bond with orality. Further questions have arisen as to what folk literature's relationship might be with the written variety. A nother approach has been to trace evidence of orally-based 'folklore' within literary and printed sources. ${ }^{27}$ Kirk and M artin drew upon folk material just as Burns incorporated local legend in 'Tam o' Shanter', as did Scott relentlessly. Perhaps, in conclusion, the relationship is best summed up as reciprocity, to the enrichment of both.

\section{F urther Reading}

A. J. Bruford and D. A. M acDonald, eds. Scottish Traditional Tales. Edinburgh: Polygon, 1994.

David Buchan. Scottish Tradition: A Collection of Scottish Folk Literature. London: Routledge and K egan Paul, 1984. 
David Buchan. 'Folk Tradition and Literature Till 1603' in J.D. McClure and M.R.G. Spiller (eds), Bryght Lanternis: Essays on the Language and Literature of Medieval and Renaissance Scotland. A berdeen: A berdeen University Press, 1989. pp. 1-13.

Lizanne Henderson, ed. F antastical Imaginations: The Supernatural in Scottish History and Culture. Edinburgh: J ohn Donald, 2009.

Lizanne Henderson and Edward J. Cowan. Scottish Fairy Belief: A History. 2001. Edinburgh: John Donald, 2011.

1 Lizanne Henderson, 'Studying the Supernatural History of Scotland', in Lizanne Henderson (ed.), F antastical Imaginations: The Supernatural in Scottish H istory and Culture (Edinburgh: J ohn Donald, 2009), p. xvi.

2 On the unitary, binary, trinary and general characteristics of folktale see A xel Olrik, 'E pic Laws of Folk Narrative' (1909), reprinted in A lan Dundes (ed.), The Study of F olklore (Englewood Cliffs: Prentice-Hall, 1965), pp. 131-41; V ladimir Propp, M orphology of the F olktale (1928; A ustin: n.p., 1968).

3 Reidar Thoralf Christiansen, The Migratory Legends (Helsinki: Folklore Fellows Communications, 1958), Stith Thompson, M otif-Index of F olk Literature, 6 vols.

(Bloomington: Indiana University Press, 1955-8), and A ntti A arne and Stith Thompson, The Types of the F olktale (Helsinki: A cademia Scientiarum Fennica, 1961).

4 W illiam M otherwell, 'Preface', in A ndrew Henderson, Scottish Proverbs (Edinburgh: Oliver and Boyd, 1832), p. xxix.

${ }^{5}$ R obert Chambers, The P opular Rhymes of Scotland, (1826; 1841; London and Edinburgh: W \& R Chambers, 1870), pp. vi, 48.

6 David Buchan, Scottish Tradition (L ondon: R outledge and K egan Paul, 1984), p. 11.

7 Lizanne Henderson, " "D etestable Slaves of the Devil": Changing A ttitudes to W itchcraft in Sixteenth-Century Scotland', in Edward J. Cowan and Lizanne Henderson (eds), A History of Everyday Life in Medieval Scotland (Edinburgh: Edinburgh University Press, 2011), pp. 226-53; Lizanne Henderson, 'W itch, Fairy and Folktale Narratives in the Trial of B essie Dunlop', in F antastical I maginations, pp. 141-66.

8 'The Legend of the Bischop of St A ndrois L yfe, callit M r Patrik A damsone' (1583) in J ames Cranstoun (ed.), Satirical Poems of the Time of the Reformation, 2 vols., Scottish Text Society (Edinburgh: W illiam Blackwood and Sons, 1891) vol. 1, p. 362 and notes; Lizanne Henderson and Edward J. Cowan, Scottish F airy Belief: A H istory (2001; Edinburgh: J ohn Donald, 2007), pp. 165-8.

${ }^{9}$ Stewart Sanderson (ed.), The Secret Common-Wealth of Elves, F auns and F airies (Cambridge: M istletoe Press, 1976) p. 1.

10 Sanderson (ed.), The Secret Common-Wealth, pp. 54, 60, 61, 95.

11 On pre-1603 folk narrative see David Buchan, 'Folk Tradition and Literature Till 1603', in J.D. M cClure and M.R.G. Spiller (eds), Bryght Lanternis: Essays on the Language and Literature of M edieval and Renaissance Scotland (A berdeen: A berdeen U niversity Press, 1989), pp. 1-13. 
${ }^{12}$ R obert H. Cromek, Remains of Nithsdale and Galloway Song: with Historical and Traditional Notices Relative to the Manners and Customs of the Peasantry, (London: Cadell and Davies, 1810; Paisley: A lexander Gardner, 1880), pp. xxx-xxi.

${ }^{13}$ Cromek, Remains, pp. 272-93; A llan Cunningham, Traditional Tales of the English and Scottish Peasantry, 2 vols. (London, 1822).

${ }^{14}$ Cromek, Remains, pp. 276-7.

${ }^{15}$ Cromek, Remains, pp. 277-80.

${ }^{16}$ J ames Grant, Walks and Wanderings in the World of Literature, 2 vols. (L ondon:

Saunders and Otley, 1839) vol. 2, pp. 189-201; William Henderson, Notes on the F olklore of the Northern Counties of England and the Borders (1866; London: The Folklore Society, 1879).

${ }^{17}$ Tale-types 'the youth transformed into a horse' and 'the magic bridle', A arne and Thompson, The Types of the Folktale, A T 314 and A T 594.

${ }^{18}$ Cromek, Remains, p. 291.

19 Lizanne Henderson, 'The Survival of Witch Prosecutions and Witch Belief in SouthW est Scotland', Scottish Historical Review LXXX V, 1: N 0. 219 (2006), pp. 52-74.

${ }^{20}$ Cromek, Remains of Nithsdale and Galloway Song, 330-38.

${ }^{21}$ W illiam Henderson noted this tradition in B erwickshire, N otes on the F olk L ore of the Northern Counties of England and the Borders (L ondon: Longmans, Green and Co., 1866), p. 209.

${ }^{22}$ Cromek, Remains, pp. 332-3.

${ }^{23}$ W illiam Nicholson, 'The B rownie of Blednoch', The Poetical Works of William Nicholson (3rd edn. Castle Douglas: Samuel Gordon, 1878) 77-82.

24 Edward J. Cowan, 'M iller's Tale: Narrating History and Tradition', in Lester Borley (ed.), C elebrating the Life and Times of Hugh M iller (Cromarty A rts Trust and the Elphinstone Institute of the U niversity of A berdeen, 2003), pp. 76-88.

${ }_{25}$ Lizanne Henderson, 'The N atural and Supernatural W orlds of Hugh M iller' in Borley (ed.), pp. 89-98.

${ }^{26}$ J ames Robertson (ed. and intro.), Scenes and Legends of the North of Scotland (1835; Edinburgh: B \& W, 1994), pp. 269-76.

27 'Introduction', in M ary Ellen B rown and B ruce A. R osenberg (eds), Encyclopedia of Folklore and Literature (Santa B arbara: A BC-CLIO, 1998). 